\title{
Pharmacoepidemiological Analysis of Statins Dispensing Patterns in Pharmacy Practice - Profile and Side Effects
}

\author{
Milena D. Deljanin ${ }^{1}$, Mira H. Vuković ${ }^{2}$ \\ ${ }^{1}$ College for preschool teachers, Krusevac, Serbia \\ ${ }^{2}$ Health Center of Valjevo, Valjevo, Serbia
}

\section{SUMMARY}

Introduction: Modern way of life contributes to the ever increasing incidence of atherosclerosis and associated cardiovascular disease. Accordingly, prescribing of statins, drugs used for primary and secondary prevention of cardiovascular events, gains momentum worldwide. The aim of this study was to analyze profile of drug dispensing, side effects frequency and correlation with treatment duration.

Subjects and methods: The study included 44 randomly selected patients who used statins. The length of the follow-up was a one month, in the outpatient pharmacy situated in the city of Belgrade, where patients filled out the survey. Data were statistically analyzed and presented in tables and graph enclosed.

Results: PResults showed that it is more frequent use of these drugs in secondary prevention of cardiovascular events, than in primary. Likewise, there is a significant difference in distribution between different therapy duration categories and indication $\left(\chi^{2}=7.726 ; p=0.021\right)$ and significant difference in distribution between different categories in weight gain $\left(\chi^{2}=11.535 ; p=0.003\right)$. The average ages of respondents were $66.93 \pm 7.65$ years, and average duration of therapy 31.68 months.

Conclusion: Based on the results, it can be concluded that the use of statins is justified in primary prevention up to 32 months of duration. After this period additional measures concerning its justification are required. From the standpoint of pharmacovigilance, it is necessary to frequently conduct the evaluation of prescriptions and use of these drugs, in order to prevent side effects.

Keywords: hyperlipidemia, pharmacovigilance, treatment duration, prevention 


\section{INTRODUCTION}

Hyperlipidemia is the leading risk factor for the development of atherosclerosis and atherosclerotic cardiovascular disease, such is ischemic heart disease, cerebrovascular disease and peripheral vascular disease [1-4]. These diseases are a major cause of morbidity and mortality in middle-aged and elderly population. These non-communicable "prosperity diseases" bear significant work load and financial burden for the health system particularly among the subpopulation of elderly [5-7]. It is estimated that in 2008 in Serbia, even 49.8 $\%$ of persons older than 25 years had elevated cholesterol levels in the blood, with a higher incidence in males from $52 \%$, while the percentage of women were $47.4 \%$ [ 8 ]

Searching for drugs, which, in comparison with the change of diet and lifestyle, will be more efficient and faster, experienced golden age after 1994 when the Scandinavian study showed efficacy of simvastatin for secondary prevention of coronary artery disease, and after 1995, when the study was published in Scotland wherein pravastatin significantly reduced the mortality rate in patients with primary hypercholesterolemia $[9,10]$.

The results of the Heart Protection Study, conducted on diabetic patients show that the use of simvastatin decreased cardiovascular mortality for more than $25 \%$, independent of cholesterol levels, gender and age. Precisely this study, conducted on a large number of respondents, shows that there are a number of indications for statins uses. They can be used in the primary or the secondary prevention of cardiovascular events, as well as in patients with type 2 Diabetes mellitus, and the age limit was moved to 80 years $(28 \%$ of respondents had 80 years) [11]. Huge budget impact of diabetic patients outsourcing from this exceptional consumer demand for medical services has been documented in local evidence [12].

According to data British heart foundation, in England has increased the number of prescribing statins from 290000 to 52 million in the period from 1981 to 2008. Large number of patients these drugs purchased without a prescription. According to the analysis of 2008, carried out in Canada, most frequently used statin was rosuvastatin, in a dose of $10 \mathrm{mg}$, followed by atorvastatin in a dosage of 10 and $20 \mathrm{mg}$, and for them, simvastatin and pravastatin in a dosage of 20 and $40 \mathrm{mg}$ [13].

Recent researches have shown that statins have a neuroprotective effect, thus creating the possibility of their use in new therapeutic areas, such as the therapy of Alzheimer's disease and other neurological disorders $[14,15]$. Due to the aforementioned, as well as potential new indications, it is realistic to expect a further increase in the issuance and use of such drugs, and therefore are not negligible side effects of these drugs. Muscular disorders, ranging from asymptomatic increase in creatine kinase to rhabdomyolysis, have been most frequently discussed side effects of these drugs. The risk of rhabdomyolysis is less when it comes to statin monotherapy. The incidence of this undesirable effect, based on the studies done in the United States at 6 months of hospitalized patients, 0.44 in 10,000 patients, wherein the incidence increases in the combination therapy with a fibrate, to 5.98 in 10,000 patients [16].

The risk of these side effects is the dose-dependent, and increased with the simultaneous use of drugs that inhibit the metabolism of the statin in the liver, such as itraconazole, erythromycin and cyclosporine [17]. As potential risk factors for the development of rhabdomyolysis are listed female gender, older age, hypothyroidism, Diabetes mellitus, kidney and liver decreased function, but this is not confirmed by clinical trials or observational studies.

The aim of the study is to estimate statins consumption, drugs that were dispensed on prescription or bought without it, in consultation with a physician, in sample of the adult population of the city of Belgrade. Population profile that uses these drugs was considered, an indication and the average duration of use, as well as the frequency of the most common side effects. Followed statins were atorvastatin, simvastatin, pravastatin and rosuvastatin. This research was largely driven by great upward trend in statins volume of sales and utilization in terms of defined daily doses (DDD) driven by transformation of regional pharmaceutical markets over the past decade $[18,19,20]$.

\section{MATERIALS AND METHODS}

\section{Study design}

Design of present study was conducted by type of survey research, for a time period from $15^{\text {th }}$ December 2013 to $15^{\text {th }}$ January 2014 in out- 
patient pharmacy situated in Belgrade. Questionnaire had two parts. The first part had a general nature and provides information about years, gender, sex and drug indication (hyperlipidemia with, or without cardiovascular event). In this part, there were issues related to the drug itself, drug name, dose and the manner of issuing drug (with or without a prescription). Second part was related to the side effects of the medicine, through a threelevel scale, where patient was able to assess the prevalence of side effects from the questionnaire, and to add unusual adverse reaction, which appeared for the time of drug therapy. Adverse reactions whose presence the patient assessed are: loss of appetite, weight increase, ringing in the ears, nose bleeding, changes in the glucose level in the blood, dizziness, pain in joints and muscles, increase in liver enzymes levels, leg cramps, numbness of extremities and allergic reactions.

\section{Study participants}

In the study participated 44 randomly selected patients, that used statins, whether with prescription, or without it, with doctor's recommendation. All were residents of the City of
Belgrade. There weren't limitations affecting sex, gender, professions, demographic or other characteristics.

\section{Statistical analysis}

Numerical data were presented as mean \pm standard deviation, while categorical variables were expressed as frequency. To determine correlation between therapy duration and side effects score, curve estimation was used. Cut point values for therapy duration were determined, in which significant distribution changes of side effect scores. To estimate the difference between categorical variable groups, $\chi 2$ test was used. $\mathrm{P}$ values less than 0.05 were considered significant. Statistical analyses were performed in SPSS, version 15 (Chicago, Illinois).

\section{RESULTS}

During the one-month survey, 44 patient were interviewed, 22 men and 22 women. The oldest patient had 85 , and the youngest 54 years. There was not significant statistical difference in ages between $\operatorname{sex}(t=0.410, \mathrm{df}=42, \mathrm{p}=0.666)$. Hyperlipidemia with or without cardiovascu-
Figure 1. Nonlinear effect of statin therapy duration on the total score of the frequency and intensity of adverse events.

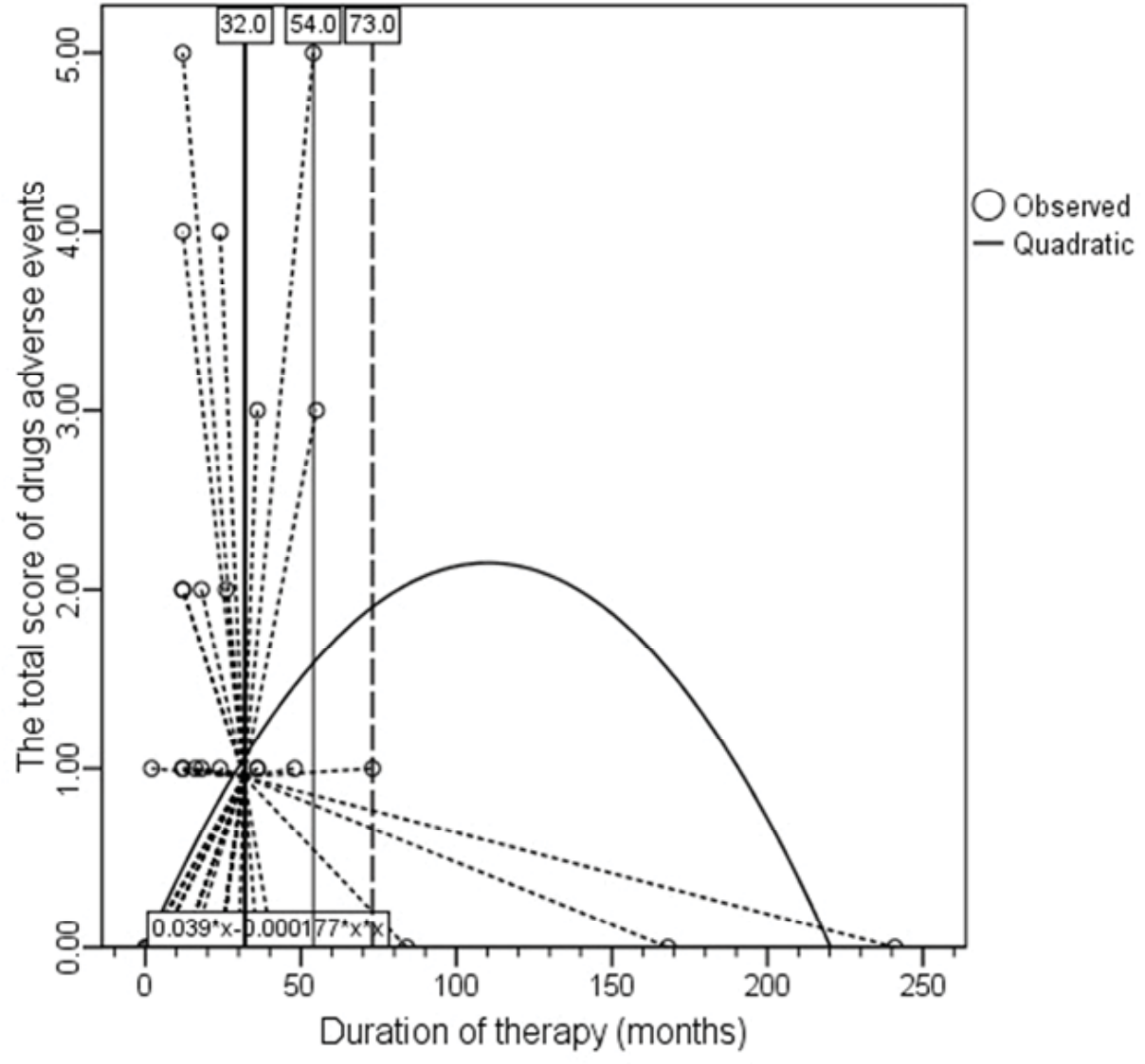




\begin{tabular}{|l|c|c|c|c|c|}
\hline \multicolumn{1}{c}{ Unstandardized Coefficients } & Standardized Coefficients & \multicolumn{2}{c|}{} \\
\hline \multicolumn{1}{c}{ Predictors } & $\mathrm{B}$ & $\mathrm{SE}$ & $\mathrm{Beta}$ & $\mathrm{t}$ & $\mathrm{p}$ \\
\hline $\begin{array}{l}\text { Duration of therapy } \\
\text { (months) }\end{array}$ & 0.039 & 0.009 & 1.221 & 4.170 & 0.00015 \\
\hline $\begin{array}{l}\text { Duration of therapy } \\
\text { (months) }\end{array}$ & 0.000177 & 0.00005 & -1.033 & -3.529 & 0.001 \\
\hline
\end{tabular}

lar event were present at 26 and 18 respondents, respectively. There were no significant differences in drug indication between sex $(\chi 2=0.228, \mathrm{df}=1)$.

The most used statin was atorvastatin $(50 \%)$, then rosuvastatin $(20.5 \%)$, simvastatin $(18.2 \%)$ and pravastatin (11.4\%). Average therapy duration was 31.68 months.

The results showed that there was a non-linear relation of therapy duration and total score of side effects frequencies and intensity (Figure 1).

Mentioned impact was shown with polynomial equitation of second degree ( $\mathrm{F}=8.806, \mathrm{df} 1=2, \mathrm{df} 2=42, \mathrm{p}=0.001)$. The parameters of the quadratic equation are pre- sented in table 1 .

In figure 1, there was a uniform distribution of absence in cases of side effects (score $=0$ ) and occasional presence of one side effect (score $=1$ ), and occasional presence two or more side effects, or permanent present of one unwanted outcome (score $>1$ ) for the average therapy duration in this study (32 months). However, after 54 months of treatment period, there was absence of occasional presence two or more, or steadily presence one or more side effects (score $>1$ ). Therefore, variable duration of therapy was transform in categorical variable with three modalities, as treatment duration: less or equal to 32 months (category 1), longer than 32 months and less or equal to

\begin{tabular}{|c|c|c|c|c|c|c|c|}
\hline \multirow[b]{2}{*}{ Variables } & \multirow[b]{2}{*}{ Categories } & \multicolumn{3}{|c|}{ Duration of therapy (categories) } & \multirow[b]{2}{*}{ Total } & \multirow[b]{2}{*}{$x^{2}$} & \multirow[b]{2}{*}{$\mathrm{p}$} \\
\hline & & $\begin{array}{l}\text { less or } \\
\text { equal to } \\
32 \text { months }\end{array}$ & $\begin{array}{l}\text { longer than } 32 \\
\text { months and less or } \\
\text { equal to } 54 \text { months }\end{array}$ & $\begin{array}{l}\text { longer } \\
\text { than } 54 \\
\text { months }\end{array}$ & & & \\
\hline \multirow{2}{*}{ Hyperlipidemia } & $\begin{array}{l}\text { without CV } \\
\text { events }\end{array}$ & 17 & 0 & 1 & 18 & \multirow{2}{*}{7.726} & \multirow{2}{*}{0.021} \\
\hline & $\begin{array}{l}\text { with CV } \\
\text { events }\end{array}$ & 15 & 7 & 4 & 26 & & \\
\hline \multirow{2}{*}{$\begin{array}{l}\text { Mode of the } \\
\text { drug issue }\end{array}$} & $\begin{array}{l}\text { with } \\
\text { prescription }\end{array}$ & 16 & 6 & 4 & 26 & \multirow{2}{*}{4.051} & \multirow{2}{*}{0.132} \\
\hline & $\begin{array}{l}\text { without } \\
\text { prescription }\end{array}$ & 16 & 1 & 1 & 18 & & \\
\hline \multirow{2}{*}{ Gender } & male & 16 & 5 & 1 & 22 & \multirow{2}{*}{3.086} & \multirow{2}{*}{0.214} \\
\hline & female & 16 & 2 & 4 & 22 & & \\
\hline \multirow[b]{2}{*}{ Weight gain } & absent & 31 & 4 & 5 & 40 & \multirow[b]{2}{*}{11.535} & \multirow[b]{2}{*}{0.003} \\
\hline & $\begin{array}{l}\text { occasionally } \\
\text { present }\end{array}$ & 1 & 3 & 0 & 4 & & \\
\hline \multirow{3}{*}{ Joint pain } & absent & 27 & 6 & 4 & 37 & \multirow{3}{*}{0.568} & \multirow{3}{*}{0.967} \\
\hline & $\begin{array}{l}\text { occasionally } \\
\text { present }\end{array}$ & 4 & 1 & 1 & 6 & & \\
\hline & $\begin{array}{l}\text { always } \\
\text { present }\end{array}$ & 1 & 0 & 0 & 1 & & \\
\hline \multirow{3}{*}{ Muscle pain } & absent & 28 & 7 & 4 & 39 & \multirow{3}{*}{1.817} & \multirow{3}{*}{0.769} \\
\hline & $\begin{array}{l}\text { occasionally } \\
\text { present }\end{array}$ & 3 & 0 & 1 & 4 & & \\
\hline & $\begin{array}{l}\text { always } \\
\text { present }\end{array}$ & 1 & 0 & 0 & 1 & & \\
\hline \multirow{2}{*}{$\begin{array}{l}\text { Changes in } \\
\text { blood glucose } \\
\text { level }\end{array}$} & absent & 27 & 5 & 4 & 36 & \multirow[b]{2}{*}{0.660} & \multirow[b]{2}{*}{0.719} \\
\hline & $\begin{array}{l}\text { occasionally } \\
\text { present }\end{array}$ & 5 & 2 & 1 & 8 & & \\
\hline
\end{tabular}

Table 1. Quadratic function parameters of influence of the duration of statin therapy on the overall score frequency and intensity of adverse events
Table 2. Indications display, ways of issuing drug, sex and the frequent occurrence of adverse reactions by category statin therapy duration 
54 months (category 2), and longer than 54 months (category 3). Further, relationship between obtained categories and drug indication was tested.

There were no significant differences in the distribution of various categories of duration of treatment by gender, as well as the manner of issuing of statins (Table 2.).

Results showed that there was significant difference in distribution between different therapy duration categories and indication $(\chi 2=7.726, p=0.021)$. Categories 2 and 3 had a higher proportion of patient with cardiovascular event, than category 1 (Table 2.). There was a significant difference in distribution between different categories in weight gain $(\chi 2=11.535$; $\mathrm{p}=0.003$ ).

\section{DISCUSSION}

In academic pharmacoepidemiology and pharmacovigilance questionnaries have long become standard tools for acquiring reliable data $[21,22]$. Results of this study showed that people which use statins most commonly found in the seventh decade of life $(66,93 \pm 7,65)$, as opposed to the indigenous populations of England, in which these drugs had been used most frequently in persons in the sixth decade [23]. It is significantly more frequent use of these drugs in patients with hyperlipidemia and CV events, than in patients who have only hyperlipidemia, without $\mathrm{CV}$ event.

According to the survey results, the most used statins were atorvastatin and rosuvastatin, respectively. These results differ from the results of studies carried out in Serbia in the period from 2004 to 2008, after which it is actually the most used statin simvastatin, in a percentage higher than 50\% [24]. The increasing use of atorvastatin relative to the simvastatin can be attributed to the higher efficiency of this drug in cholesterol-lowering effect [25]. Likewise, it can be expected increasing use of rosuvastatin, as has been demonstrated its higher efficiency compared to equivalent doses of other drugs in this group, including atorvastatin [26]. In the above-mentioned study in England, $70 \%$ of patients have used simvastatin, atorvastatin $22.3 \%$, while rosuvastatin is used by only about $1.9 \%$ of patients [23]. $70 \%$ of respondents used these drugs on prescription, while the remaining $30 \%$ of patients purchased medications from this group of drugs.

In patients were not recorded cases of rhabdomyolysis, which is rare side effect (the incidence is less than $0,01 \%$ [23].In the study there were no unusual side effects or the effects were provided outside the borders. This can be explained by the fact that the side effects are dose-dependent and doses used in Serbia are not high, compared to some countries, in which are used even dose of $80 \mathrm{mg}$ of atorvastatin, where the risk of serious side effects, especially rhabdomyolysis, doubles [27].

It is known that the occasional interruption of statin therapy (once a year for a period of one to two months) is advisable, for the prevention of adverse outcomes of therapy. In this study was shown that such a practice is not enough, and that it should pay attention to the fact that the duration of statin therapy had a nonlinear effect on the frequency and intensity of adverse events commonly associated with their use. So, it is quite justified in this way, to prevent adverse reactions to 32 months of therapy. However, after 32 months of treatment with statins, it is necessary to introduce additional precautions related to the prevention of weight gain, which teams up with a higher incidence of CV events. Conversely, after 32 months, as well as after 54 months of therapy, the frequency and intensity of the common side effects of statin therapy were almost clinically insignificant. Therefore, after 32 months of treatment with statins, it is necessary for patients with hyperlipoproteinemia to take care of diet nutrition and intensify physical activity.

\section{CONCLUSION}

Modern life, which entails rising stress and less concern about adequate nutrition and physical activity, contributes to damaging health and the increasing number of patients suffering from cardiovascular diseases. Therefore, it is expected increase of statins use in the treatment or as a measure of primary prevention. Due to a number of adverse effects it is necessary to exert constant evaluation of adverse effects and prescribe these drugs when the benefits outweigh the risks.

\section{REFERENCES}

1. Nicolas WS. Epidemiology, classification, and modifiable risk factors of peripheral arterial disease. Vasc Health Risk Manag 2007; 3(2): 229-234.

2. Al Mahameed A. Peripheral Arterial Disease. 
Cleavlande clinic, Center for Continuing Education. Disease Management 2009.

3. Lui GK, Fernandes S, McElhinney DB. Management of cardiovascular risk factors in adults with congenital heart disease. J Am Heart Assoc 2014;3(6):e001076.

4. Moons P, Van Deyk K, Dedroog D, Troost E, Budts W. Prevalence of cardiovascular risk factors in adults with congenital heart disease. Eur J Cardiovasc Prev Rehabil 2006; 13:612-616.

5. Lazic Z, Gajovic O, Tanaskovic I, Milovanovic D, Atanasijevic D, Jakovljevic MB. GOLD stage impact on COPD direct medical costs in elderly. Journal of Health Behavior and Public Health 2012; 2(3):1-7.

6. Radovanović A, Dagović A, Jakovljević M. Economics of cancer related medical care: worldwide estimates and available domestic evidence. Archive of oncology 2011; 19(3-4):59-63.

7. Ogura S, Jakovljevic M. Health financing constrained by population aging - an opportunity to learn from Japanese experience. Ser J Exp Clin Res 2014; 15(4):175-181. DOI: 10.2478/SJECR 2014 0022.

8. Susanne Løgstrup, Sophie O’Kelly (Eds). European Cardiovascular Disease Statistics European Heart Network and European Society of Cardiology: Brussels: 2012

9. Scandinavian Simvastatin Survival Study Group. Randomized trial of cholesterol lowering in 4444 patients with coronary heart disease: The Scandinavian Simvastatin Survival Study. Lancet 1994; 344:1383-1389.

10. Shepherd J, Cobbe SM, Ford I et al. Prevention of coronary heart disease with pravastatin in men with hypercholesterolemia. NEJM 1995;333:13011317.

11. MRC/BHF Heart Protection Study of cholesterollowering with simvastatin in 5963 people with diabetes: a randomised placebo-controlled trial. Lancet 2003; 361:2005-2016.

12. Biorac N, Jakovljević, MB, Stefanović, D, Perović $\mathrm{S}$, Janković, S. Assessment of diabetes mellitus type 2 treatment costs in the Republic of Serbia. Vojnosanitetski pregled 2009; 66(4):271-276.

13. Madlaina CS, Christan R. Cost-effectiveness analysis of rosuvastatin versus atorvastatin, simvastatin and pravastatin from a Canadian health system perspective. EACPT 2008; 30(7):1345-1357.

14. Cuchiara B, Kasner SE. Use of statins in CNS disorders. J Neurol Sci 2001; 187(1-2):81-9.

15. Rosella C, Placido B, Silvia M. Role of statins in the treatment of multiple sclerosis. Pharmacological Research 2014; 87:133-143.

16. David JG, Judy AS, Deborah S, Susan EA, Stephanie DS, Lois LG, Jerry HG, Arnold KC, Michael JG,
Richard P. Incidence of hospitalized Rhabdomyolysis in Patients treated with lipid-lowering drugs. JAMA 2004; 2929: 2585-2590.

17. Ucar M, Bjorndal T, Dahlqvist R. HMG-CoA reductase inhibitors and myotoxicity. Drug Saf 2000; 22:441-457.

18. Jakovljevic MB. Health Expenditure Dynamics in Serbia 1995-2012. Hospital Pharmacology 2014; 1(3):180-183. UDC: 614(497.11)"1995/2012 pp/ 180-183.

19. Petrusic T, Jakovljevic M. Budget impact of publicly reimbursed prescription medicines in The Republic of Srpska. Front Public Health - Epidemiology 2015. doi: $10.3389 /$ fpubh.2015.00213.

20. Jakovljevic MB, Djordjevic N, Jurisevic M, Jankovic S. Evolution of the Serbian pharmaceutical market alongside socioeconomic transition. Expert Review of Pharmacoeconomics Outcomes Research 2015;15(3):521-530.

21. Vuković MH, Jakovljević MB. Structural validity and reliability of the healthcare professionals' economic reasoning questionnaire. Hospital Pharmacology 2015; 2(3):308-316.

22. Vuković M, Gvozdenović BS, Gajić T, Gajić BS, Jakovljević M, McCormick BP. Validation of a patient satisfaction questionnaire in primary health care. Public Health 2012; 126(8):710-718.

23. Hippisley-Cox J, Coupland C. Unintended effects of statins in men and women in England and Wales: population based cohort study using the QResearch database. BMJ 2010; 340:c2197.

24. Sabo A, Tomić Z, Stilinović N, Milijašević B, Mikov M, Vukmirović S, Horvat O. Comsumption of serum lipid-reducting drugs in Serbia compared with Scandinavian countries: a population-based study, 2004-2008. Pharmacoepidemiology and Drug Safety 2011; 20(1):45-49.

25. Jones $\mathrm{P}$, Kafonek S, Laurora I, Hunninghake D. Comparative Dose Efficacy of Atorvastatin Versus Simvastatin, Pravastatin, Lovastatin and Fluvastatin in patients with Hypercholesterolemia, (The CURVES Study). The American Journal of Cardiology 1998; 81(5):582-587.

26. Jones PH, Davidson MH, Stein EA et al. Comparison of the efficacy and safety of rosuvastatin versus atorvastatin, simvastatin, and pravastatin across doses (STELLAR * Trial). The American Journal of Cardiology 2003; 92(2):152-160.

27. Sinzinger $H$, Wolfram R, Peska BA. Muscular side effects of statins. Journal of Cardiovascular Pharmacology 2002; 40(2):163-171. 


\title{
Farmakoepidemiološka analiza dispenzionih uzoraka statina u farmaceutskoj praksi - profil i neželjeni efekti
}

\author{
Milena D. Deljanin ${ }^{1}$, Mira H. Vuković ${ }^{2}$ \\ ${ }^{1}$ Visoka škola strukovnih studija za vaspitače u Kruševcu,Kruševac, Srbija \\ ${ }^{2}$ Zdravstveni centar Valjevo, Valjevo, Srbija
}

\section{KRATAK SADRŽAJ}

Uvod: Savremeni način života doprinosi sve većoj učestalosti ateroskleroze i pridruženih kardiovaskularnih bolesti. Shodno tome, propisivanje statina, lekova koji se koriste u primarnoj i sekundarnoj prevenciji kardiovaskularnih događaja, dobija zamah širom sveta. Cilj ove studije je da analizira profil izdavanja, učestalost neželjenih dejstava i njihovu povezanost sa dužinom terapije.

Subjekti i metode: Studija je obuhvatila 44 slučajno odabrana pacijenta koji su koristili statine. Dužina praćenja pacijenata bila je mesec dana, u vanbolničkoj apoteci koja se nalazi u gradu Beogradu, gde su pacijenti popunjavali anketu. Podaci su statistički analizirani i prikazani tabelarno i grafički.

Rezultati: Rezultati su pokazali da je češća upotreba ovih lekova u sekundarnoj prevenciji kardiovaskularnih događaja, nego u primarnoj. Isto tako, postoji značajna razlika u distribuciji između različitih kategorija terapije po indikaciji primene $\left(\mathrm{x}^{2}=\right.$ 7.726; $p=0,021)$ i značajna razlika u distribuciji između različitih kategorija po dobijanju u telesnoj masi $\left(x^{2}=11.535 ; p=0,003\right)$. Prosečna starost ispitanika je $66.93 \pm$ 7.65 godina, a prosečno trajanje terapije 31.68 meseci.

Zaključak: Na osnovu dobijenih rezultata, može se zaključiti da je upotreba statina opravdana u primarnoj prevenciji do 32 meseca terapije. Nakon ovog perioda potrebne su dodatne mere opreza. Sa stanovišta farmakovigilance, potrebna je češća evaluacija propisivanja statina, kako bi se sprečili neželjeni efekti.

Ključne reči: hiperlipidemija, farmakovigilanca, dužina terapije, prevencija 